\title{
Teachers' Perspectives towards Teaching English Online at the Tertiary Level in Saudi Arabia
}

\author{
Ghazi Algethami \\ Department of Foreign Languages \\ Taif University, Saudi Arabia \\ Email: g.gethami@tu.edu.sa
}

Received: 11/29/2021

Accepted: $1 / 8 / 2022$

Published: $1 / 24 / 2022$

\begin{abstract}
The drastic and unplanned shift to online teaching caused by the Covid-19 pandemic offers researchers with unprecedented opportunity to examine a wide range of issues related to online language teaching and assessment. The current study surveyed English language teachers $(N=$ 161) from several Saudi universities regarding their experience with teaching English online. Five themes were explored: institutions' resources and technical support, knowledge and training, attitudes, effectiveness of teaching and assessment, and overall experience. The results demonstrate the readiness of Saudi universities for online teaching in terms of resources and technical support. In addition, teachers were found to have the necessary knowledge and training needed to carry out their online teaching and assessment. Teachers' attitudes were mixed towards teaching English online, which may be due to personal preferences and different teaching contexts. The same was also found for their opinions towards the effectiveness of online teaching and assessment as compared to in-person teaching and assessment. While the teachers' experiences were largely positive towards online teaching, concerns were raised regarding student engagement and assessment reliability. Saudi universities are recommended to capitalize on what they have achieved during the pandemic and offer innovative solutions to enhance assessment reliability and student engagement.
\end{abstract}

Keywords: English teaching, online, teachers' perspectives, Saudi Arabia, university Cite as: Algethami, G. (2022). Teachers' Perspectives towards Teaching English Online at the Tertiary Level in Saudi Arabia. Arab World English Journal (AWEJ) $2^{\text {nd }}$ Special Issue on Covid 19 Challenges (2) 317-328. DOI: https://dx.doi.org/10.24093/awej/covid2.21 
Arab World English Journal (AWEJ) 2nd Special Issue on Covid 19 Challenges January 2022

Teachers' Perspectives towards Teaching English Online

Algethami

\section{Introduction}

The outbreak of Covid-19 has disrupted all forms of human face-to-face (F2F) communication. Many schools and academic institutions have resorted to online teaching and assessment in order to sustain their activities. The impact of this abrupt and unplanned switch to online teaching can be especially detrimental to the quality and outcomes of certain subjects and courses, such as foreign language education, where interaction between students and teachers plays a key role in the delivery of the curriculum (Todd, 2020). At the same time, the sudden switch to online teaching offers a unique chance for researchers to examine online language teaching as the magnitude of change is unprecedented in the history of education. The need for more studies to examine online language teaching is urgent as it is no longer optional but a necessity to teach online (Dhawan, 2020).

Online teaching is not new to language education (Blake, 2011). In fact, online language teaching has been increasing over the last two decades (Manegre \& Sabiri, 2020). Previous research has shown that online language teaching can be as effective as F2F teaching (e.g., Blake, Wilson, Cettor \& Pardo-Ballester, 2008; Blake, 2011; Enkin \& Mejías-Bikandi, 2017; Gacs, Goertler \& Spasova, 2020; Moser, Wei \& Brenner, 2021). However, previous studies have focused on planned online language teaching, where the language course was designed and prepared in advance to be delivered online. This is different from the current international situation, where the shift to online mode was abrupt and unplanned (Hodges, Moore, Lockee, Trust \& Bond, 2020). In other words, during the current period of the Covid-19 pandemic, courses designed for F2F teaching were delivered online. This situation is worth investigating, as it allows researchers to examine the readiness of institutions and teaching staff to teach language online and to identify any major obstacles that may impede the successful delivery of online language teaching.

In March 2020, as a safety and precautionary measure, universities in Saudi Arabia had to close temporarily during the Covid-19 pandemic and deliver all their courses, including English language courses, online via virtual learning environments. Teachers are at the forefront of the teaching process, and their perspectives are expected to shed light on the success and challenges of online language teaching. Thus, the current study explores the perspectives of English language teachers in Saudi universities regarding teaching English online. It does so by examining the technical capacity and support of their institutions, their knowledge and training for teaching online, their attitudes towards online teaching, and their perceptions of the effectiveness of online teaching and assessment.

\section{The Context of the Current Study}

In March 2020, in an attempt to stop the spread of Covid-19, the Ministry of Education in the Kingdom of Saudi Arabia decided to temporarily close down all schools and higher education institutions. The closure was lifted in August 2021, and universities were permitted to allow their students to attend F2F classes. During the closure period, all universities had to deliver their courses online.

Owing to the Kingdom's heavy investment in information and communication technologies over the last few years, the disruption to teaching during the sudden switch to online delivery was minimal in higher education. The Ministry of Education, as part of its implementation of the 
digital transformation initiative in the Saudi Vision 2030, had invested heavily in education technology well before the COVID-19 pandemic. All students and faculty at Saudi public universities have had full access to Blackboard services, and a few courses were even delivered online a few years before the COVID-19 pandemic.

Blackboard Inc is an educational technology company that provides technological services to academic institutions all over the globe. Two of its widely used systems are Blackboard Learn and Blackboard Collaborate. Blackboard Learn is a learning management system that provides a communication platform between teachers and students. Using the system, teachers can upload course materials, receive and mark students' assignments, and assess their students' learning. Blackboard Collaborate provides a virtual classroom environment where teachers can conduct their online classes. Teachers and students can talk and see each other in real time. It also has a chat box, a screen sharing feature, and a whiteboard. Both systems, Blackboard Learn and Blackboard Collaborate, were fully functional in all Saudi public universities during the pandemic.

General and academic English language courses are taught in all Saudi universities as part of students' preparatory year or as part of their university general requirements. Universities, though, vary in the number and nature of English language courses they offer to their students. As is the case with all university courses during the closure, English language courses were delivered fully online via Blackboard Learn and Blackboard Collaborate.

\section{Research Objective}

The abrupt and complete switch to online teaching, especially in the case of language teaching where interaction between teachers and students is instrumental to the learning process, offers a unique opportunity for researchers, curriculum designers, and policy makers to examine the pros and cons of teaching English online, as well as the challenges and obstacles that may stand in the way of the successful implementation of online English language teaching.

The shift to online language teaching during the COVID-19 pandemic is unprecedented in magnitude and nature; it was an unplanned and complete shift. For this reason, and because of the lack of a solid and cumulative research base, the current study opted to explore the overall perspectives of English language teachers rather than focusing on a specific aspect of online teaching.

The objective of the current study is to explore teachers' perspectives regarding teaching English online in Saudi universities in an attempt to identify pedagogical implications for relevant stakeholders.

\section{Literature Review}

Online language teaching is a broad term that can refer to different "learning arrangements: a web-facilitated class, a blended or hybrid course, or a fully virtual or online course" (Blake, 2011, p. 19). The terms synchronous and asynchronous are also commonly used to differentiate between two different types of online teaching delivery. Online synchronous courses are delivered in real time, while asynchronous courses are available online and can be accessed at any time (Meskill \& Anthony, 2015). 
Arab World English Journal (AWEJ) 2nd Special Issue on Covid 19 Challenges January 2022

The current study focuses on fully online, synchronous courses, where all teaching is delivered online (Goertler, 2019). Many of these courses are delivered through virtual classroom systems (e.g., Blackboard) which offer many features, such as videoconferencing and digital learning materials (Manegre \& Sabiri, 2020). These virtual classrooms have the advantages of being flexible, adaptive, interactive, and easily monitored (Gacs et al., 2020; Goertler, 2019; Manegre \& Sabiri, 2020). However, there are some obstacles to the optimal utilization of virtual classrooms, such as the lack of technical training and support, students' internet access, and student engagement (Dhawan, 2020; Gacs et al., 2020; Manegre \& Sabiri, 2020).

There is some emerging evidence indicating that planned online language teaching can be as effective as F2F teaching (e.g., Blake et al., 2008; Blake, 2011; Enkin \& Mejías-Bikandi, 2017; Gacs et al., 2020; Moser et al., 2021). It is not yet clear whether the same effectiveness can be attained in the current wide and unplanned use of online language teaching. The last two years have witnessed an influx of research examining online learning and teaching during the COVID19 pandemic (e.g., Gacs et al., 2020; Gavranović \& Prodanović, 2021; Manegre \& Sabiri, 2020; Moser et al., 2021; Todd, 2020). Because of the widely varied contexts in which these studies have been conducted, their results may not be applicable to all language teaching contexts.

In the Saudi context, the same surge in the amount of research examining online language teaching from the perspectives of students has also been witnessed in the last two years (e.g., AlNofaie, 2020; Almekhlafy, 2020; Alsuhaibani, 2021; Alzamil, 2021; Mahyoob, 2020; Oraif \& Elyas, 2021). However, fewer studies have examined teachers' perspectives towards online language teaching in Saudi Arabia (Hakim, 2020; Khafaga, 2021; Rahman, 2020).

Although many of the teachers in Hakim (2020) showed a positive attitude towards the use of Blackboard in teaching English online, they also reported facing some challenges, such as weak internet connection and low student motivation and attention. Hakim (2020) examined the opinions of teachers from one institution, and thus her results may not be applicable to the wider context of EFL in Saudi higher education. Rahman (2020) surveyed the opinions of 50 English language teachers from three universities in Saudi Arabia. Most of the teachers indicated that they were offered the appropriate technology and had the knowledge to teach English online. On the other hand, many of the teachers agreed that student-teacher interaction and student motivation were among the challenges encountered during their online teaching. Only $20 \%$ of the teachers believed that online teaching is more effective than F2F teaching. Khafaga (2021) investigated the attitudes of 29 English language teachers from five Saudi universities. Most of the teachers acknowledged that they did not have the required experience to use Blackboard. Given this acknowledgment, it is surprising that most of them also agreed that teaching English via Blackboard can be as effective as teaching English in traditional classrooms. Unsurprisingly, given the nature of remote teaching, most of the teachers doubted the credibility of student assessment. The current study examines a larger sample size (161 teachers \& 14 universities) to provide a more representative picture of the unplanned shift to teaching English online in Saudi universities from the perspectives of teachers. In addition, the current study surveyed teachers one year after their involvement in teaching English online so to make sure they had formed firm opinions about their online teaching experience. 
Arab World English Journal (AWEJ) 2nd Special Issue on Covid 19 Challenges January 2022

Teachers' Perspectives towards Teaching English Online

Algethami

\section{Method}

\section{Instrument}

A Likert-scale questionnaire was designed to examine the overall perspectives of English language teachers regarding teaching English online in Saudi public universities. The Likert scale consisted of five points, where one represented strong disagreement and five represented strong agreement. The questionnaire consisted of 22 items, of which the first four items asked for the teachers' demographic information. The remaining 18 items were divided into five sections: resources and technical support, knowledge and training, attitudes, teaching and assessment effectiveness, and overall perception. In addition, an optional open-ended question was added to the end of the questionnaire to allow the teachers to add anything about their online teaching experience that was not covered in the questionnaire. The survey was uploaded to Google Forms and a link was created. An official request along with the survey link was sent by email to the chairs of several English language institutes and centers in Saudi public universities. They were requested to share the survey with their English language teachers.

\section{Participants}

Responses were received from 161 teachers from 14 Saudi public universities. They were 133 females and 28 males, and they were of different age groups (85 were in the age group 30-40 years, 38 in the age group 20-30 years, 31 in the age group 40-50 years, and six in the age group 50-60 years). In terms of their years of experience teaching English, 107 of them had more than five years of experience, 27 had three years of experience, 20 had two years of experience, and eight had only one year of experience. For the open-ended question, which was added to the end of the survey, only 37 participants responded.

\section{Analysis}

The data obtained from the Likert-scale questionnaire were analyzed by means of distribution of responses for each statement. The first and second points in the scale were collapsed to indicate disagreement and the fourth and the fifth points were collapsed to indicate agreement. The third point represented a neutral position; neither in agreement nor in disagreement. The open-ended question was analyzed qualitatively using thematic analysis (Braun \& Clarke, 2006). The participants' responses were read carefully, and general themes were identified and discussed in relation to the research objective.

\section{Findings and Discussion}

\section{Questionnaire Data}

The results from the questionnaire data are presented and discussed below under five sections. For each section, a table including the percentages of agreement and disagreement for each statement is presented first, followed by interpretations and discussions.

Resources and Technical Support

Table 1. Institutions' provision of resources and technical support

\begin{tabular}{|l|l|l|l|}
\hline Items & Disagree & Neutral & Agree \\
\hline $\begin{array}{l}\text { My institution provides me with the technological resources and infrastructure } \\
\text { needed to effectively deliver teaching online }\end{array}$ & $5.6 \%$ & $23 \%$ & $71.4 \%$ \\
\hline $\begin{array}{l}\text { My institution provides me with the technological resources and infrastructure } \\
\text { needed to assess my students reliably }\end{array}$ & $10.5 \%$ & $21.7 \%$ & $67.7 \%$ \\
\hline $\begin{array}{l}\text { My institution provides me with the technical support needed to solve any } \\
\text { difficulty I encounter }\end{array}$ & $7.4 \%$ & $18 \%$ & $74.6 \%$ \\
\hline
\end{tabular}


Arab World English Journal (AWEJ) 2nd Special Issue on Covid 19 Challenges January 2022

Teachers' Perspectives towards Teaching English Online

Algethami

The majority of the participants agreed that their institutions provided them with the technological infrastructure and the technical support they needed for delivering their courses online. This is in line with the findings of Rahman (2020) where the majority of teachers acknowledged that their universities provided them with the appropriate tools to conduct online teaching. These findings clearly indicate the success of the national efforts in Saudi Arabia to implement the Kingdom's digital transformation plans. These plans have evidently helped to minimize the detrimental effect of university campus closures.

\section{Knowledge and Training}

Table 2. Teachers' online teaching knowledge and training

\begin{tabular}{|l|l|l|l|}
\hline Items & Disagree & Neutral & Agree \\
\hline I have the knowledge and training needed to effectively teach online & $1.8 \%$ & $6.2 \%$ & $92 \%$ \\
\hline $\begin{array}{l}\text { I have the knowledge and training needed to effectively and reliably assess } \\
\text { students online }\end{array}$ & $3.7 \%$ & $15.5 \%$ & $80.8 \%$ \\
\hline $\begin{array}{l}\text { My institution provides me with the training needed to effectively implement } \\
\text { online teaching and assessment }\end{array}$ & $9.3 \%$ & $13.7 \%$ & $77 \%$ \\
\hline
\end{tabular}

Similar to the results obtained for resources and technical support, the majority of teachers agreed that they had the required knowledge and training to teach and assess students online. The majority also agreed that their institutions provided them with the training needed for online teaching and assessment. Rahim (2020) found similar results when he asked his teacher participants whether they had the required computer and IT skills to conduct their online classes. In contrast, the majority of teachers in Khatanga (2021) agreed with the statement "I do not have enough technical experience to use Blackboard". It is difficult to explain this contradiction; however, it may have something to do with the statement itself being a negative statement while most of the items in his questionnaire were positive statements. Some evidence in the literature suggests that such survey design practice may confuse survey takers (Roszkowski \& Soven, 2010).

While Rahim (2020) and Khafaga (2021) asked their teacher participants specifically about their technical knowledge, the current study asked about their overall knowledge and training, both technical and pedagogical, needed for effectively teaching and assessing online classes. However, it is possible that the participants in the current study focused only on the technical part when they responded to the questionnaire items. Therefore, it is difficult to reach any firm conclusion about the actual knowledge and training of teachers regarding online language teaching. Given the large and sudden switch to online teaching, one would assume that teachers need training to effectively deliver their online classes. In fact, $82 \%$ of the teachers surveyed in Rahman (2020) indicated a desire for more training on online teaching.

\section{Teachers' Attitudes}

Table 3. Teachers' attitudes towards online teaching

\begin{tabular}{|c|c|c|c|}
\hline Items & Disagree & Neutral & Agree \\
\hline $\begin{array}{l}\text { I feel as confident teaching and assessing English online as I do in face-to-face } \\
\text { classrooms }\end{array}$ & $2.5 \%$ & $20.5 \%$ & $67 \%$ \\
\hline Teaching online is more enjoyable than teaching in traditional classrooms & $37.9 \%$ & $32.9 \%$ & $29.2 \%$ \\
\hline Teaching online is more tiring than teaching face-to-face & $27.3 \%$ & $33.5 \%$ & $39.2 \%$ \\
\hline $\begin{array}{l}\text { Students are more engaged and motivated to learn online than in traditional } \\
\text { classrooms }\end{array}$ & $57.7 \%$ & $25.5 \%$ & $16.7 \%$ \\
\hline I find it difficult to communicate with students online & $33.5 \%$ & $34.8 \%$ & $31.7 \%$ \\
\hline
\end{tabular}


Arab World English Journal (AWEJ) 2nd Special Issue on Covid 19 Challenges January 2022

Teachers' Perspectives towards Teaching English Online

Algethami

I feel helpless in managing my class online

$64 \%$

$21.1 \%$

$15 \%$

The results showed some agreement among the teachers on student management and engagement. A considerable percentage of the teachers agreed that students were less engaged and motivated during online classes. These findings are in line with the results of Hakim (2020) and Rahman (2020), who both pointed out teachers' concerns regarding student motivation and engagement in online classes. The majority of teachers agreed that they did not face much difficulty in managing their classes online.

The highest agreement among teachers in this section of the questionnaire was on their confidence in teaching and assessing students online. The majority indicated that they felt confident delivering their classes online. A similar finding was reported by Gavranović and Prodanović (2021), though in a different context. As expected, personal preferences yielded mixed results. Teachers had different opinions regarding how tiring and enjoyable online classes are for them. The same was found for communication with students. This can be, at least partially, attributed to the differences in the contexts of their classes (i.e., number of students and course type).

\section{Effectiveness of Teaching and Assessment}

Table 4. Effectiveness of online teaching and assessment

\begin{tabular}{|c|c|c|c|}
\hline Items & Disagree & Neutral & Agree \\
\hline Teaching online is less effective than teaching face-to-face & $28 \%$ & $28.6 \%$ & $43.5 \%$ \\
\hline $\begin{array}{l}\text { Teaching online provides a better learning environment for language teaching } \\
\text { than does teaching face-to-face }\end{array}$ & $40.9 \%$ & $39.1 \%$ & $19.9 \%$ \\
\hline Online assessment is less valid and reliable than face-to-face assessment & $22.3 \%$ & $26.7 \%$ & $50.9 \%$ \\
\hline $\begin{array}{l}\text { Online assessment is easier to deliver and mark than traditional classroom } \\
\text { assessment }\end{array}$ & $11.2 \%$ & $19.2 \%$ & $69.6 \%$ \\
\hline
\end{tabular}

The number of teachers who agreed with the proposition that teaching online is less effective than teaching $\mathrm{F} 2 \mathrm{~F}$ was almost double the number of teachers who disagreed. A similar finding was also reached by Rahman (2020). On the contrary, previous studies that have examined the effectiveness of online language teaching have shown that it can be as or more effective than F2F language teaching (e.g., Blake et al., 2008; Blake, 2011; Enkin \& Mejías-Bikandi, 2017). It should be noted, however, that these studies have examined planned online language teaching, which is different from the context examined in the current study (i.e., unplanned). In other words, the courses that were delivered by the teachers in the current study were designed to be delivered F2F. Many of the teachers disagreed with the statement that online teaching provides a better learning environment than traditional F2F classrooms. This gives further support to their opinion regarding the effectiveness of online teaching as compared to F2F teaching.

Although the majority of the teachers acknowledged the ease of online assessment, a large number of them questioned its reliability and validity. Khafaga (2021) also reported that most of his teacher participants questioned the credibility of online assessment. This is expected since there is no monitoring or invigilation in online assessment, and the likelihood of cheating is high given the summative nature of the assessment (i.e., the English courses are part of their university study plans and count into their Grade Point Average GPA). 
Arab World English Journal (AWEJ) 2nd Special Issue on Covid 19 Challenges January 2022

Teachers' Perspectives towards Teaching English Online

Algethami

Overall Perception

Table 5. Teachers' overall perception towards their online teaching experience

\begin{tabular}{|l|l|l|l|}
\hline \multicolumn{1}{|c|}{ Item } & Disagree & Neutral & Agree \\
\hline $\begin{array}{l}\text { In my context, teaching language online can offer a better alternative than face- } \\
\text { to-face mode for language teaching }\end{array}$ & $30.4 \%$ & $28.6 \%$ & $41 \%$ \\
\hline My experience of teaching English online is largely positive & $10 \%$ & $24.8 \%$ & $65.2 \%$ \\
\hline
\end{tabular}

The statement on whether online language teaching provides a better alternative to traditional F2F classrooms received mixed responses. This may reflect the differences between the teachers' contexts and personal preferences. For example, one would expect a teacher with a large class size and insufficient learning resources to agree with the statement. Regardless of these differences, the majority of the teacher participants believed that their online teaching experience was largely positive.

\section{Open-ended Question}

The open-ended question asked the teachers whether they wanted to add any extra information regarding their online teaching experience. The teachers' written responses were read many times, coded, and analyzed thematically. The results are reported below according to emergent themes.

\section{Student Motivation and Engagement}

Many of the teachers mentioned that online language teaching had a negative impact on student motivation and engagement. For example, one of the participants wrote "I notice that online teaching makes students unlikely to participate or be motivated". Another one mentioned that online teaching is only effective if "students are motivated". One of the teachers mentioned that "a lot of my energy as a teacher will go into trying to engage students". This finding gives credence to the results of the questionnaire where the majority of the teachers disagreed with the statement on students being more engaged and motivated to learn online than in traditional classrooms. Interestingly, two teachers mentioned that online teaching, on the contrary, can boost the confidence of shy and reluctant students and motivate them to be more engaged. There is some evidence in the literature suggesting that the use of computer-mediated communication can reduce the anxiety some students have when they speak a foreign language (e.g., Côté \& Gaffney, 2021).

\section{Accessibility}

Many of the teachers mentioned that online teaching is more accessible to students than F2F classrooms. Students can access their classes anywhere, anytime. A few teachers also mentioned that online teaching can save both students' and teachers' time, and one of the respondents referred to online teaching as "a time saver". Some teachers mentioned that online teaching saved some of the time they used to waste on taking students' attendance and dividing them into groups. One teacher also mentioned that "online lectures can be recorded, archived, and shared for future reference" which also increases accessibility to classes. Another teacher wrote that "the best part about online teaching is providing students with asynchronous content that they can access at any time, in addition to online quizzes that are easily accessible to students". 
Some of the respondents mentioned that online classes are easier to manage than F2F traditional classrooms. They mentioned that they could easily follow their students' activities and effectively manage their class times. At the same time, they also raised some concerns with regard to managing students online. Two obstacles were mentioned: students' unwillingness to use their cameras and large class sizes. For example, one of the teachers wrote: "If students had their cameras on then it would be a lot easier to know if they are in fact doing the work themselves". Another teacher wrote: "In the context of higher education in Saudi, large classes are a major issue in online classes". Although large classroom size is also an issue in F2F English classrooms in Saudi universities (Al Asmari, 2015), it can be more challenging in online classes because of students' unwillingness to use their cameras. These obstacles can affect the quality of teacher-student interaction which is of importance to language teaching.

\section{Assessment}

Although the questionnaire included statements about the reliability and validity of online assessment, the reliability of online assessment emerged as a main theme. Several teachers cast doubt on the reliability of online assessment. This gives further support to the questionnaire finding in which the majority of the participants agreed that online assessment is less reliable than in-person classroom assessment. One of the participants mentioned that "the worst part about online teaching is assessment". Another wrote: "Although assessment in online teaching is easier for teachers, it is not as accurate as face-to-face assessment for students. Some students find unethical ways to complete their assignments in order to get full marks". It is clear from the teachers' responses that students cheating is a major threat to the reliability of online assessment.

\section{Conclusion}

Through examining the perspectives of teachers, a number of conclusions can be drawn from the current study with regard to teaching English online in the Saudi higher education context. It should be reiterated at this juncture that these conclusions cannot be extended to planned online language teaching, as the current study only examined forced and unplanned online teaching.

English language teachers in Saudi public universities have access to the technological resources and support needed to effectively conduct their online classes. This shows the success of national efforts towards digital transformation. In addition, teachers seem to possess the required knowledge and training for teaching English online. However, it is not clear what this knowledge entails. Future research may explore in more detail teachers' knowledge and training needs for online teaching.

Although many of the teachers agreed to the proposition that in their contexts online teaching can provide a better learning environment for language teaching than does $\mathrm{F} 2 \mathrm{~F}$ teaching, the majority of them believed that online teaching is less effective than F2F teaching. The results of the current study revealed some of the obstacles that may impact the effectiveness of online language teaching. The unreliability of online assessment is one of the major challenges that teachers face. The teachers raised concerns about the possibility of students finding unethical ways to achieve higher marks due to the lack of proper invigilation or monitoring. In addition, the majority of teachers believed that online teaching had negatively affected their students' motivation and engagement. The qualitative data also revealed students' unwillingness to use their cameras and large class sizes as two major challenges faced by the 
Arab World English Journal (AWEJ) 2nd Special Issue on Covid 19 Challenges January 2022

teachers when trying to manage their online classes. These challenges can also affect the quality of communication in online language classes.

\section{Pedagogical Implications}

Online language teaching can provide a good alternative to $\mathrm{F} 2 \mathrm{~F}$ classrooms, especially in situations where conducting F2F classes is not feasible. However, Saudi higher education institutions should take measures to assure the reliability of online summative assessments. They can make use of some of the current technological and innovative ways to monitor students during their online tests, such as the use of artificial intelligence systems. Teachers should also find creative ways to motivate and engage their students in the learning process. They can do so by adopting more student-centered teaching activities. Communication and interaction are integral parts of any language class, so universities should limit the number of students in each class to a level in which students have sufficient opportunity to communicate and interact in the target language. In addition, and to enhance communication as well as classroom management, students should be encouraged to use their cameras whenever possible.

\section{About the Author:}

Dr. Ghazi Algethami is an Associate Professor in Linguistics at Taif University. He is interested in second/foreign language speech. In particular, he is interested in how second/foreign language speech is perceived and produced, and what factors may affect learners' learning of second/foreign language speech (e.g., language use and pronunciation instruction). https://orcid.org/0000-0003-0575-9529

\section{References}

Al-Nofaie, H. (2020). Saudi University Students' Perceptions towards Virtual Education during COVID-19 Pandemic: A Case Study of Language Learning via Blackboard. Arab World English Journal, 11(3), 4-20. https://doi.org/https://dx.doi.org/10.24093/awej/vol11no3.1

Al Asmari, A. A. (2015). Communicative language teaching in EFL university context: Challenges for teachers. Journal of Language Teaching and Research, 6(5), 976-984. https://doi.org/http://dx.doi.org/10.17507/j1tr.0605.09

Almekhlafy, S. (2020). Online learning of English language courses via blackboard at Saudi universities in the era of COVID-19: perception and use. PSU Research Review, 5(1), 16-32.

Alsuhaibani, Z. (2021). Saudi EFL Students' Use and Perceptions of Blackboard before and during Online Learning Amid COVID-19. Arab World English Journal Special Issue on CALL, 7, 22-37. https://doi.org/https://dx.doi.org/10.24093/awej/call7.2

Alzamil, A. (2021). Teaching English Speaking Online versus Face-to-Face: Saudi Students' Experience during the COVID-19 Pandemic. Arab World English Journal, 12(1), 19-27. https://doi.org/https://dx.doi.org/10.24093/awej/vol12no1.2

Blake, R., Wilson, N. L., Cetto, M., \& Pardo-Ballester, C. (2008). Measuring oral proficiency in distance, face-to-face, and blended classrooms. Language Learning \& Technology, $12(3), 114$.

Blake, R. J. (2011). Current trends in online language learning. Annual review of applied linguistics, 31, 19-35. https://doi.org/10.1017/S026719051100002X 
Arab World English Journal (AWEJ) 2nd Special Issue on Covid 19 Challenges January 2022

Braun, V., \& Clarke, V. (2006). Using thematic analysis in psychology. Qualitative research in psychology, 3(2), 77-101. https://doi.org/10.1191/1478088706qp063oa

Côté, S., \& Gaffney, C. (2021). The effect of synchronous computer-mediated communication on beginner L2 learners' foreign language anxiety and participation. The Language Learning Journal, 49(1), 105-116. https://doi.org/https://doi.org/10.1080/09571736.2018.1484935

Dhawan, S. (2020). Online learning: A panacea in the time of COVID-19 crisis. Journal of Educational Technology Systems, 49(1), 5-22. https://doi.org/https://doi.org/10.1177/0047239520934018

Enkin, E., \& Mejías-Bikandi, E. (2017). The effectiveness of online teaching in an advanced Spanish language course. International Journal of Applied Linguistics, 27(1), 176-197. https://doi.org/https://doi.org/10.1111/ijal.12112

Gacs, A., Goertler, S., \& Spasova, S. (2020). Planned online language education versus crisisprompted online language teaching: Lessons for the future. Foreign Language Annals, 53(2), 380-392. https://doi.org/https://doi.org/10.1111/flan.12460

Gavranović, V., \& Prodanović, M. (2021). ESP Teachers' Perspectives on the Online Teaching Environment Imposed in the Covid-19 Era-A Case Study. The New Educational Review, 64 (2), 188-197.

Goertler, S. (2019). Normalizing online learning: Adapting to a changing world of language teaching. In N. Arnold \& L. Ducate (Eds.), From theory and research to new directions in language teaching (pp. 51-92). Equinox.

Hakim, B. (2020). Technology integrated online classrooms and the challenges faced by the EFL teachers in Saudi Arabia during the Covid-19 pandemic. International Journal of Applied Linguistics and English Literature, 9(5), 33-39. https://doi.org/http://dx.doi.org/10.7575/aiac.ijalel.v.9n.5p.33

Hodges, C. B., Moore, S., Lockee, B. B., Trust, T., \& Bond, M. A. (2020). The difference between emergency remote teaching and online learning. Educause Review. https://er.educause.edu/articles/2020/3/the-difference-between-emergency-remoteteaching-and-online-learning

Khafaga, A. F. (2021). The perception of blackboard collaborate-based instruction by EFL majors/teachers amid COVID-19: A case study of Saudi universities. Journal of Language and Linguistic Studies, 17(2), 1160-1173.

Mahyoob, M. (2020). Challenges of e-Learning during the COVID-19 Pandemic Experienced by EFL Learners. Arab World English Journal, 11(4), 351-362. https://doi.org/https://dx.doi.org/10.24093/awej/vol11no4.23

Manegre, M., \& Sabiri, K. A. (2020). Online language learning using virtual classrooms: an analysis of teacher perceptions. Computer Assisted Language Learning, Ahead of Print May 2020, 1-16. https://doi.org/https://doi.org/10.1080/09588221.2020.1770290

Meskill, C., \& Anthony, N. (2015). Teaching languages online. Multilingual Matters.

Moser, K., Wei, T., \& Brenner, D. (2021). Remote teaching during COVID-19: Implications from a national survey of language educators. System, 97, 102431.

Oraif, I., \& Elyas, T. (2021). The Impact of COVID-19 on Learning: Investigating EFL Learners' Engagement in Online Courses in Saudi Arabia. Education Sciences, 11(3), 119. https://doi.org/https://doi.org/10.3390/educsci11030099 
Arab World English Journal (AWEJ) 2nd Special Issue on Covid 19 Challenges January 2022

Rahman, M. (2020). Challenges and Solutions of Teaching English as a Foreign Language Online during a Global Pandemic like COVID-19: Saudi EFL Teachers' Perspectives. Journal of Southwest Jiaotong University, 55(6), 1-9.

Roszkowski, M. J., \& Soven, M. (2010). Shifting gears: Consequences of including two negatively worded items in the middle of a positively worded questionnaire. Assessment \& Evaluation in Higher Education, 35(1), 113-130. https://doi.org/https://doi.org/10.1080/02602930802618344

Todd, R. W. (2020). Teachers' perceptions of the shift from the classroom to online teaching. International Journal of TESOL Studies, 2(2), 4-16. https://doi.org/ https://doi.org/10.46451/ijts.2020.09.02 